\title{
AREAS OF PROFESSIONAL JOB REQUIRED BY EMPLOYERS AND UNIVERSITY TRAINING IN SOME LATIN AMERICAN COUNTRIES
}

\author{
Hortensia Hickman Rodríguez, Rosalva Cabrera Castañon, \\ Patricia Plancarte Cansino \\ National Autonomous University of Mexico (UNAM), Mexico \\ E-mail: hortensiahickman@gmail.com,rosalva@unam.mx, patyplancarte@gmail.com
}

\begin{abstract}
The purpose of this research is to describe the requirements that psychologists must meet as per required by employers in different Latin American countries and their connection with professional training programs. Three countries were selected Chile, Mexico and Colombia, and as criteria for their selection was the ranking obtained in the Program for International Student Assessment (PISA). For data collection, web pages were visited. A sample for each country was taken monthly from January to May in the year 2009. All of the job listings for psychologists were registered and also those activities that a psychologist could perform, in spite of the fact that the offer specifically did not mention such professional. The university plans and programs of a representative public university of each country of interest were checked. In general terms we can point out that the psychology professionals that employers require the most are those specialized in the training area in organizations with an emphasis on training, recruitment and selection activities.
\end{abstract}

Key words: employers, psychology, Latin American countries, university plans.

\section{Introduction}

Tension, in some cases, irreconcilable, in and out of Higher Education Institutions (HEIS), is a common occurrence. Certain positions promote a large gap between the demands of the market and the training practices of professionals; whereas others, support the unrestricted adjustment of university plans and programs to the logic of the market. In this respect, it is important to stress that the logic of training is different from the logic of the labor market. Likewise, is essential for curriculums to be prepared based on a prospective vision of the societies that will receive the professionals in training, in other words, trying to balance the changes societies have experienced as an effect of globalization, jointly with the unique social aspects of each country (Reynaga \& Ruiz, 2003).

Frequently, it seems that study plans focus on matters aimed at strengthening a discipline while putting the demands of society to one side. This can cause problems such as an unbalance between the training received in the universities and employers' hiring requirements of employers an over qualification of the hired professionals; and of course an increase in the unemployment rate.

As a part of the effect of globalization and crises in the economic systems, several investigations have reported that the gross unemployment rate in Latin America and Europe, over the last years, has ranged between 6.2 and 22.8 percent, in social science disciplines and humanities, as well as in exact sciences (De Vries \& Navarro, 2011). Undoubtedly, this has had a direct impact on the university 
training system, and not only on the economic and social systems of the different countries. One of the forms in which universities have tried to mitigate the effects of the different economic crises, Volume 3, 2012 has been through the diversification and expansion of the training offer (Barbado, Alonso \& Castro, 2005), training critical-thinking professionals but also highly qualified and sufficiently versatile to respond to the demands of a highly heterogeneous labor market (López Moguel, 2009).

In this context, the existing relation between the economic activity and the skills and knowledge that professionals must have has received special attention, due to the fact that training of human resources constitutes one of the most important challenges of Higher Education Institutions (Barrón \& Ysunza, 2003; Muñoz-Izquierdo, 1997, Reynaga \& Ruiz, 2003), especially if we accept that socio - economic, demographic and cultural changes have a bearing on the change of occupations (Mungaray, Ocegueda \& Moctezuma, 2006; Peiró, 2003). Proof thereof, is that economic and commercial projects of global corporations, require more qualified professional performances that are sufficiently flexible with a view to the adjustment of changing demands nowadays (Villamil, 2005).

Although these events have an impact on most professions, they have differential effects in relation with the type of discipline. Such is the case of Psychology, which is one of the professions with the highest training demand from students in Mexico and in some Latin American countries. The unbalance between the training of professionals and the actual number of young people that become a part of the labor market, has resulted in the fact that currently there is a high number of overqualified professionals in regard to the work that they perform, but also an increase in employers' hiring standards. For the great demand of work of psychology professionals, Castro Solano (2004) proposes keeping a census of the most required professional profiles in different places as a strategy to face the problem. This census would include indicators such as the salaries offered by employers, professional experience of applicants and their hiring conditions, among other; due to which it might serve as a guide on the tendencies that employers follow as far as the most hired professional is concerned.

On the other hand, even though the overpopulation of psychology professionals has an economic and social effect; higher education institutions that train psychologists have a challenge of training qualified professionals while simultaneously facing the explosive growth that this discipline has gone through ever since its institutionalization as a profession. In Mexico, for example, psychology is among the ten most demanded professions by young people, and as an example of its exponential growth, Zannata \& Yurén (2012) point out that in the mid 90's in the past century there were approximately 30,000 psychology students and by the year 2005 there were already 290 Schools and Faculties where Psychology could be studied.

This expansion is not exclusive of Mexico, it is a phenomenon experienced in most Latin American countries. Puche-Navarro (2008) points out that in the year 1992 there were 16 psychology programs per university in Colombia and by the year 2008 these had increased to 131 programs. On the other hand, Álvarez, Gómez \& Ratto (2004) sustain that in the case of Chile in the decade of the 80 's of the last century, 100 students enrolled to study psychology every year, a figure that has grown annually in an 18.8 percent in a steady form.

This data is alarming due to the fact that the high number of these professionals produces an excessive offer and therefore a higher pressure on the market in regard with the skills and competencies that the new professionals must have; one of the effects is a very tough competition for work. These data also emphasize the importance of systematically analysing the relation between the training that students receive during their professional studies, the school levels reached by the students and the needs of employers.

The purpose of this empirical study was to describe the requirements that psychologists must meet as per required by employers in different Latin American countries and their connection with professional training programs. In a previous study (Cabrera, Hickman \& Mares, 2010), identified that the requirements and activities that Mexican employers demanded from psychology professionals varied according to the level of socio - economic welfare of the states of the country reviewed. This data served as a guide for this research which lead to ask whether the activities and professional practice areas that were demanded by employers varied among the different countries, in relation with their socio- economic position. 


\section{Methodology of Research}

A similar methodology to the one of the study by Cabrera, Hickman \& Mares, was followed in these empirical research, as far as the strategy for collecting the job applications and for the data analysis. As a criterion for the selection of the countries we took the ranking obtained in the Program for International Student Assessment (PISA) during the year 2006. The PISA test is a test of knowledge applied to 15 year old students of the countries that were a part of the Organization for Cooperation and Development (OCDE). Mexico was situated as the country of reference, Chile as the country which level was above PISA ranking, and Colombia as the country below the ranking.

Information Sources. For data collection, web pages that work as online labor exchange sites such as www.computrabajo.com.mx, www.computrabajo.com.cl and www.computrabajo.com.co were visited. A sample for each country was taken monthly from January to May in the year 2009. Procedure. All of the job listings for psychologists were registered, including the activities that they could be carried out. Taking into consideration the analysis carried out by Cabrera and collaborators as a criteria, a database was formed (see Table 1 some examples), taking into consideration all of the records per country in which all of the job listings were put together and information on the following indicators was analysed:

Areas of professional practice. This indicator allowed us to identify which professional areas psychologists are being required in each one of the registered openings, in other words, which is the actual field of action for a psychology professional. The categories to organize data of this indicator were:

Organization. Psychologists study the psychological processes that occur in institutions, groups, communities, associations, etc., in other words, in those contexts in which groups of people relate under certain standard principles. Their professional activities have to do with handling matters related with the participants of the group, prepare reports, plan activities, make evaluations.

Education. A psychology professional studies the psychological processes that take place in education contexts. Their professional activities are found in teaching, planning and application of educational programs, vocational and educational guidance and the preparation of didactic materials.

Clinical. The job of a psychologist consists in studying the psychological processes of users, identifying if there is a need to promote changes in the user and / or the people or conditions that surround same. His / her professional activities consist in applying tools of psychological evaluation, diagnosis, planning and application of techniques, design and / or give therapies and follow - up on the treatment of user.

Other. Professionals are required to work in professional areas that are different from those previously described.

Professional activities. This indicator allowed to know the specific tasks carried out by the required professionals in the registered job opportunities. To classify information the following categories were defined.

Administration: Personnel required to carry out tasks related with the operation of a company or institution at a financial level, infrastructure, organization, etc.

Training: Personnel required to provide training to a group of people that work in a company or institution, on a specific subject or skill related with the company's needs. Recruitment and Selection: Personnel required to carry out interviews with candidates to occupy the positions offered by a company or institution, use psychometric tests, prepare reports and suggest if the hiring of mentioned candidates is convenient or not.

Teaching: Personnel required to teach in schools.

Psychological Therapy: Personnel required to carry out activities aimed at promoting a change in user through individual and group therapies, etc.

Other: Personnel required to perform different activities from those described in the previous categories. 
Table 1 shows some examples of how the data of openings in web sites were qualified in the database.

Table 1. This table shows examples of openings registered in different webs and their a posteriori classification.

\begin{tabular}{|c|c|c|c|}
\hline Openings & Profession & Area & Activities \\
\hline $\begin{array}{l}\text { www.computrabajo.com.cl } \\
\text { Consultant. Sociologist and/or Psychologist } \\
\text { with experience of two years in organization, } \\
\text { psychodiagnosis of groups. }\end{array}$ & $\begin{array}{l}\text { Psychologist and } \\
\text { others }\end{array}$ & Organization & Diagnosis \\
\hline $\begin{array}{l}\text { www.computrabajo.com.cl } \\
\text { Clinical psychologist certified by the Chile } \\
\text { Society of Clinical Psychology for attention to } \\
\text { children and young people. }\end{array}$ & Only psychologist & Clinical & Therapy \\
\hline $\begin{array}{l}\text { www.computrabajo.com.co } \\
\text { Psychologist, minimum experience of one year } \\
\text { in organizational area and in processes of } \\
\text { massive selection, application of test, interview. }\end{array}$ & Only psychologist & Organization & $\begin{array}{l}\text { Selection: } \\
\text { application } \\
\text { of test and } \\
\text { interview }\end{array}$ \\
\hline $\begin{array}{l}\text { www.computrabajo.com.co } \\
\text { Clinical psychologist with experience in systemic } \\
\text { family therapy. }\end{array}$ & Only psychologist & Clinical & Family therapy \\
\hline $\begin{array}{l}\text { www.computrabajo.com.mx } \\
\text { Psychologist or education professional to } \\
\text { support to director of kindergarten. }\end{array}$ & $\begin{array}{l}\text { Psychologist and } \\
\text { others }\end{array}$ & Education & $\begin{array}{l}\text { Planning and } \\
\text { application of } \\
\text { educational } \\
\text { programs }\end{array}$ \\
\hline
\end{tabular}

The total number of openings registered in each one of the countries was considered as a 100 percent, and from same, the percentage of each evaluated indicator was calculated. Simultaneously to this investigation, the university plans and programs of a representative public university of each country of interest were checked. For Mexico, the study plan of the Faculty of Psychology of the National Autonomous University of Mexico; in the case of Chile, The Faculty of Social Sciences of the University of Chile and, for Colombia the National University of Colombia. Of the plans, the areas of professional practice that each curriculum offer, as well as the competencies and skills that are taught in the different programs were registered with the purpose of being able to compare the training received in university institutions against the demands required by employers.

\section{Results of Research}

The first fact to mention is related to the total frequency of requirements by employers on job boards of psychology professionals, because in the case of Chilean job openings, a total of 239 opportunities and 153 by Mexican employers were counted. Surprisingly, there was an extraordinarily high number of employment opportunities for psychology professionals -850 - by Colombian employers.

Likewise, the Figure 1 shows the total number of the proportions of each country in terms of professional practice areas and professional activities was obtained. As far as the study plans, the areas of professional training and the competencies and skills to be developed in students, were analysed. In general terms can be pointed out that the psychology professionals that employers require the most are those specialized in the training area in organizations (see graph of figure 1 above), particularly in Mexico and in Colombia. 


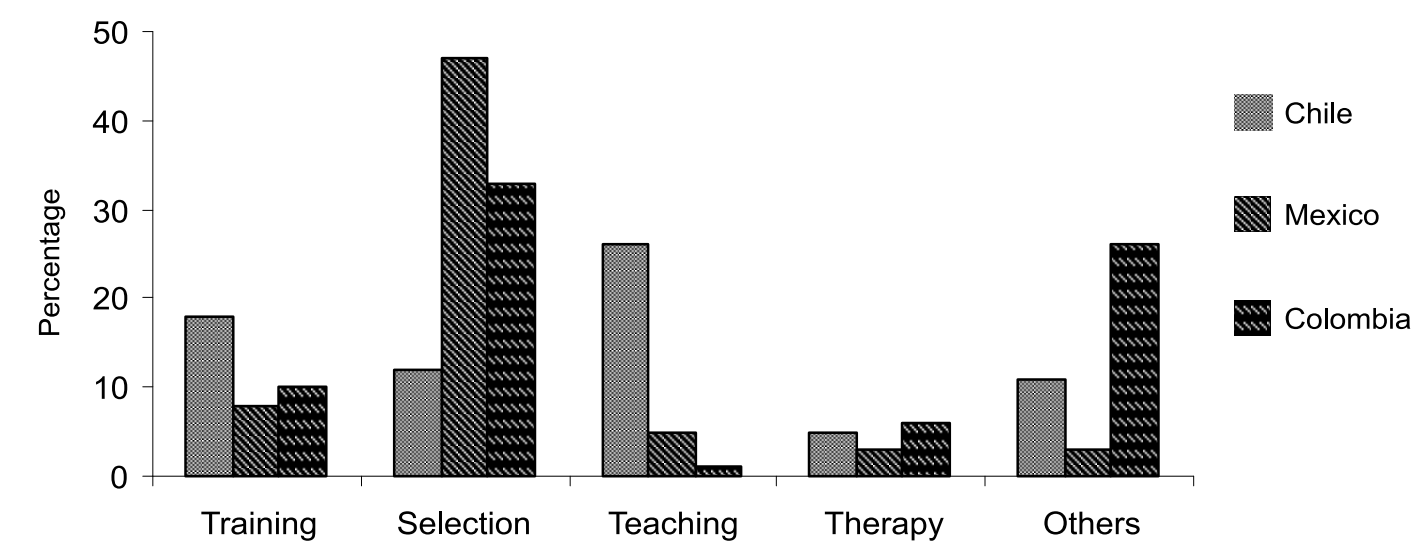

Areas of Application

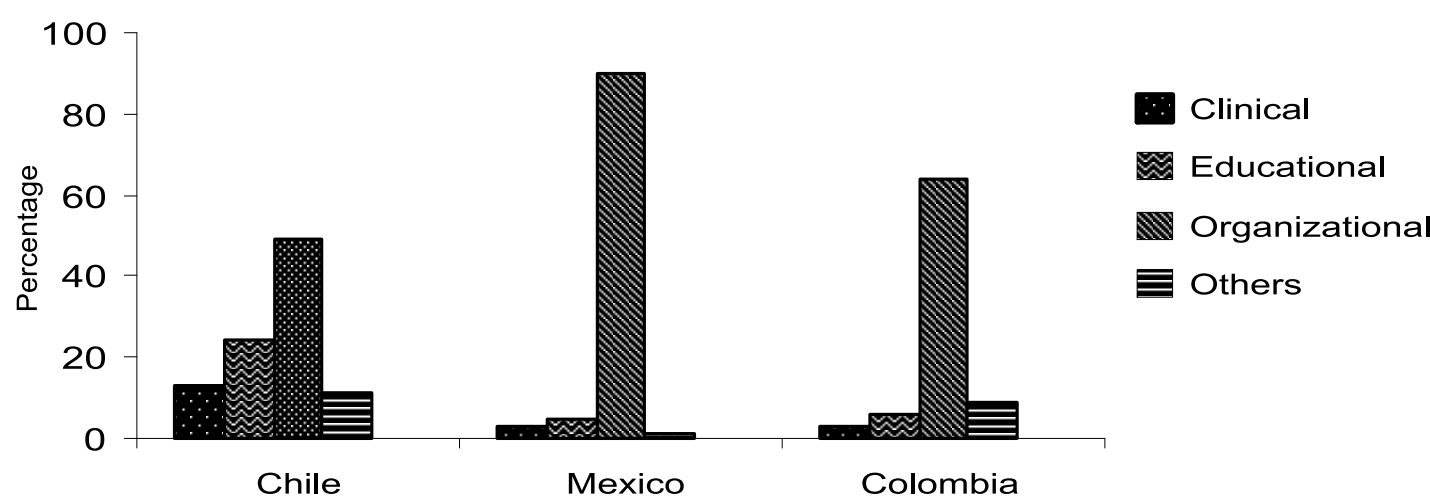

Figure 1: Shows the percentage of professional activities and areas of application in each country.

On the other hand, a common denominator in the employment opportunities collected from the three countries, is that professional training in the traditional areas dominates (see inferior graph of Figure 1), in other words, employers offer employment in the fields that historically have been of the domain of psychologists, with a minimum offer in emergent fields (in our case located in the category of "other"), the highest number of opportunities related with the area of organizations, for example, recruitment and selection and a minimum number of job opportunities for clinical activities. This effect can be due to the source through which we obtained data (online labor exchange sites on the Internet) due to the fact that the practice of the clinical profession is preferably developed in private offices. Is possible that could be used another source of information to help us confirm the data collected. Maybe this source could be the number of offices of psychologists registered before the financial departments of each country.

Table 2. Present the professional training areas and the abilities and/or aptitudes in the public universities of three countries.

\begin{tabular}{llll}
\hline \multicolumn{1}{c}{ Country } & \multicolumn{1}{c}{ University } & Professional Training Areas & Ability and/or Aptitudes \\
\hline Chile & $\begin{array}{l}\text { University of Chile (Social } \\
\text { Sciences-Psychology) }\end{array}$ & $\begin{array}{l}\text { Clinic, organization, education, } \\
\text { social }\end{array}$ & $\begin{array}{l}\text { Academic (researching), } \\
\text { prevention, diagnosis, } \\
\text { autoevaluation, intervention, } \\
\text { ethical }\end{array}$
\end{tabular}




\begin{tabular}{llll}
\hline \multicolumn{1}{c}{ Country } & \multicolumn{1}{c}{ University } & Professional Training Areas & Ability and/or Aptitudes \\
\hline Mexico & $\begin{array}{l}\text { National University of Mexico } \\
\text { (Central Campus-Psychology) }\end{array}$ & $\begin{array}{l}\text { Clinic, organization, education, } \\
\text { psychosocial-cultural, cognitive- } \\
\text { behavioural, psychobiology, } \\
\text { neuroscience's }\end{array}$ & $\begin{array}{l}\text { Academic (researching } \\
\text { and teaching), evaluation, } \\
\text { intervention, design, } \\
\text { management, training, planning }\end{array}$ \\
Colombia & $\begin{array}{l}\text { National University of } \\
\text { Colombia (Psychology) }\end{array}$ & $\begin{array}{l}\text { Clinic, organization, education, } \\
\text { social, legal, sport }\end{array}$ & $\begin{array}{l}\text { Academic (researching), } \\
\text { diagnosis, evaluation, } \\
\text { intervention }\end{array}$ \\
\hline
\end{tabular}

The Table 2 presents the professional training areas and the abilities and/or aptitudes in the public universities of three countries. An interesting fact is that the University of Chile - country situated above the ranking of reference-, considers traditional training areas in its curriculum in contrast with the Faculty of Psychology of the National Autonomous University in Mexico and the National University of Colombia, that trains sport psychologists as an emergent area. A second aspect to point out is that only the University of Chile explicitly contemplates the teaching of ethical competencies. On the other hand, what the competencies that are taught in the three universities have in common, are the teaching of investigation, diagnosis and intervention skills which have been traditionally associated with psychologists and that reinforce the identity of the discipline in its professional dimension.

\section{Conclusion}

The aim of this study was to compare the job applications of psychologists through employment exchanges in three Latin American countries located in different socioeconomic positions. We analysed the areas more requested and professional activities by employers and compared with the curricula of one public university in each country. The differences between countries overall regarding requests for psychologists applications by employers is an interesting fact since even though Colombia is located in an inferior position in relation with Mexico in the PISA ranking, and also in an inferior socio - economic position, there is a great demand in that country to hire these professionals in contrast with Chile and Mexico in which the number of opportunities between both countries is not significantly different. If the socio - economic conditions of the evaluated countries are not that unbalanced and if the history of institutionalization of the career shares more or less common temporalities as well as itineraries, what is this high demand for psychologists due to? A possible explanation of this phenomenon could be the excessive expansion that the profession has gone through in Colombia ever since the late 90's of the last century and the entering into force of the Law 30 of the Ministry of Education that regulates the plans and programs. According to PucheNavarro (2008) this legislation has had positive effects on academic psychology and its relation with the field of production.

However, is necessary that a brief study focused on identifying if other traditional or emergent professions have such a high demand could be carried out, and if so, the effectiveness of mentioned Law 30 would be corroborated and its impact would be beneficial not only in the university educational system but in the Colombian economy. A new study could be aimed at understanding "why" there is such a high demand for psychology professionals. In both cases we would have to carry out a complementary study of the economic, social, political and cultural reality of that country. In a previous study we analyzed university labor exchanges of public institutions of Mexico City and of the city of Guadalajara. A similar tendency between Mexico and Colombia in regard with organizational psychology as the most demanded area by employers with an emphasis on training, recruitment and selection activities can be seen with the data obtained; which is confirmed at a local level with the information obtained per country (Cabrera, Hickman, Mares \& Hernández, 2009).

By other hand, are psychology professionals being trained in Chile that employers also demand them in the areas of clinical psychology and education? Perhaps, a possible explanation for this more equal distribution in this country, can be associated with a higher correspondence between the training received in the educational institutions and the labor market. For example, Álvarez, Gómez 
and Ratto (2004), reported that in the private university where they studied, three of the four most demanded competencies by employers are taught. It would be important to explore if this correspondence operates in other public and private educational institutions.

In general, we can conclude that the correspondence between training in the areas of professional practice in public universities and those demanded by employers is not that narrow as it would be expected, and this can be seen in the three analyzed countries, because universities prepare their students to practice in areas that were not required in our sample, for example, sport or legal psychology. In this respect, the fact that apparently Clinical Psychology -which must be included as a training area in a curriculum-, has such little demand, is a fact that attracts attention.

Finally, it would be worthwhile for schools that train psychologists to stress the teaching of general competencies in their training plans and programs that allow students to perform in an effective form in any social and production environment, without neglecting the training in the specific competencies and skills of this professional; due to the fact that one of the substantial purposes of university education is that same has a positive impact on individuals and on the social and economic system as a whole, because as Rojas accurately points out (in: Ruiz, Jaraba \& Romero, 2008) "nowadays employers do not search for graduates exclusively with technical - professional competencies exclusively, but also with those associated with self knowledge, autonomous and group performance, tolerance before changing and ambiguous scenarios" (p. 153).

\section{Acknowledgements}

This study was supported in 2009 by PAPCA (No.41) program grant of Facultad de Estudios Superiores Iztacala, UNAM.

\section{References}

Álvarez, E., Gómez, J., Ratto, P. (2004). Competencias requeridas por el mercado laboral chileno y competencias actuales de estudiantes de Psicología con orientación laboral. Pharos, 11 (001), 113-133.

Barbado, A., Cristobal, P., Castro, L.F. (2005). Tendencias de las trayectorias de los titulados en tránsito al mercado laboral. International Journal of Psychology and Psychological Therapy, 5 (3), 233-246.

Barrón, C., Ysunza, M. (2003). Currículum y formación profesional. En: A. Díaz Barriga (Ed) La investigación curricular en México: La década de los noventa. México: Grupo Ideograma Editores.

Cabrera, R., Hickman, H., Mares, G. (2010). Perfil profesional del psicólogo requerido por empleadores en entidades federativas con diferente nivel socioeconómico en México. Enseñanza e Investigación en Psicología, 15 (2), 257-271.

Cabrera, R., Hickman, H., Mares, G., Hernández, A. (2009). El mercado de trabajo para el psicólogo: Un análisis de las bolsas de trabajo universitarias. En: H. Hickman (coordinadora). Psicología Iztacala y sus actores. México: Facultad de Estudios Superiores Iztacala, UNAM.

Castro, S. A. (2004). Las competencias profesionales del psicólogo y las necesidades de perfiles profesionales en los diferentes ámbitos laborales. Interdiciplinaria, 21 (002), 117-152.

De Vries, W., Navarro, Y. (2011). Profesionistas del futuro o futuros taxistas? Los egresados universitarios y el mercado laboral en México. Revista Iberoamericana de Educación Superior, 4 (2), 3-27.

López, M. R. (2009). Efectos de la correspondencia entre educación y empleo de los jóvenes en el mercado mexicano. Revista Mexicana de Investigación Educativa, 14 (47), 863-887.

Mungaray, A., Ocegueda, J. M., Moctezuma, P. (2001) Demanda de educación superior y especialización económica en Baja California. Revista de la Educación Superior, 35 (149), 31-48.

Muñoz-Izquierdo, C. (1997). Profesiones, mercado de trabajo y desarrollo económico. En: T. Pacheco y A. DíazBarriga (Eds) La profesión, su condición social e institucional. México: CESU-UNAM-POMARES.

Peiró, J. M. (2003). La enseñanza de la psicología en Europa. Un proyecto de titulación

Puché-Navarro, R. (2008). Trazos para un panorama de los postgrados y la investigación en Psicología en Colombia. Revista Interamericana en Psicología, 42 (3), 415-430. 
Reynaga, S., Ruiz, E. (2003). Estudios de educación y trabajo. En: S. Reynaga (Ed) Educación, trabajo, ciencia y tecnología. México: Grupo ideograma editores.

Ruíz, M., Jaraba, B., Romero, L. (2008). La formación en psicología y las nuevas exigencias del mundo laboral: Competencias laborales exigidas a psicólogos. Psicología desde el Caribe, 021, 136-157.

Villamil, P. R. (2005). El sentido ético de las nociones de utilidad y beneficio social en el origen de las profesiones frente a la globalización. En Pacheco y Díaz, B. (coord) La profesión universitaria en el contexto de la modernización. México: CESU-UNAM. Pomares. 15-46.

Zannata, E., Yurén, T. (2012). La formación profesional del psicólogo en México: Trayecto de la construcción de su identidad disciplinar. Enseñanza e Investigación en Psicología, 17 (1), 151-170.

Advised by Dalia Augiene, University of Siauliai, Republic of Lithuania 